
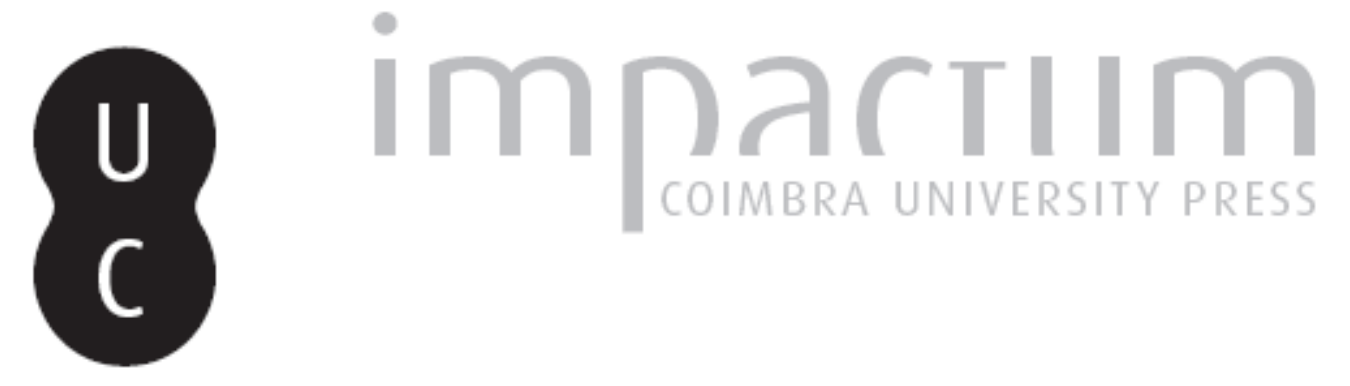

\title{
Subordinated by culture: constraints of women in elective politics in Nigeria
}

Autor(es): $\quad$ Olasunkanmi, Aborisade

Publicado por: Universidade Católica de Petrópolis

URL persistente:

URI:http://hdl.handle.net/10316.2/33929

DOI:

DOI:http://dx.doi.org/10.14195/2175-0947_6-1_1

Accessed : $\quad$ 26-Apr-2023 12:43:26

A navegação consulta e descarregamento dos títulos inseridos nas Bibliotecas Digitais UC Digitalis, UC Pombalina e UC Impactum, pressupõem a aceitação plena e sem reservas dos Termos e Condições de Uso destas Bibliotecas Digitais, disponíveis em https://digitalis.uc.pt/pt-pt/termos.

Conforme exposto nos referidos Termos e Condições de Uso, o descarregamento de títulos de acesso restrito requer uma licença válida de autorização devendo o utilizador aceder ao(s) documento(s) a partir de um endereço de IP da instituição detentora da supramencionada licença.

Ao utilizador é apenas permitido o descarregamento para uso pessoal, pelo que o emprego do(s) título(s) descarregado(s) para outro fim, designadamente comercial, carece de autorização do respetivo autor ou editor da obra.

Na medida em que todas as obras da UC Digitalis se encontram protegidas pelo Código do Direito de Autor e Direitos Conexos e demais legislação aplicável, toda a cópia, parcial ou total, deste documento, nos casos em que é legalmente admitida, deverá conter ou fazer-se acompanhar por este aviso.

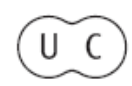



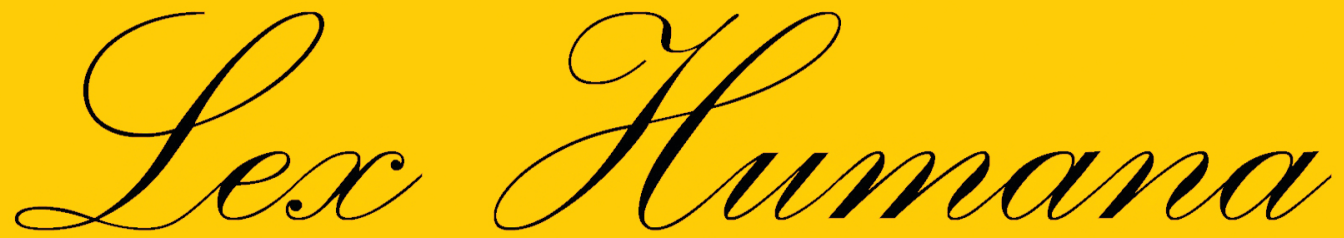

Revista do Programa de Pós-Graduação em Direito da UCP

ISSN(e) 2175-0947

Universidade Católica de Petrópolis Rua Benjamin Constant, 213 - Petrópolis - Centro CEP 25610-130

Tel: (24) 2244-4000 E-mail: lexhumana@ucp.br 


\title{
SUBORDINATED BY CULTURE: CONSTRAINTS OF WOMEN IN ELECTIVE POLITICS IN NIGERIA*
}

\author{
ABORISADE OLASUNKANMI** \\ LADOKE AKINTOLA UNIVERSITY OF TECHNOLOGY, NIGERIA
}

\begin{abstract}
Nigerian women constitute about half of the population of the country and are known to play vital roles as mother, producer, time manager, community organizer and social and political activist. However, despite these roles and the strength of their population, they are discriminated against when it comes to elective politics. The aim of the study, therefore, was to find out the specific factors responsible for the low level of political participation of women in Nigeria. The paper identified the patriarchal value system of Africa, colonialism, monetization of political contest, electoral violence, etc, as culprits and argued that existing patriarchal values should be jettisoned in favour of a more gender sensitive stance as this will allow women contribute their quota to the democratic and developmental processes in Nigeria.
\end{abstract}

Keywords: Women's participation, culture, political process, patriarchy, elective politics.

\footnotetext{
* Artigo recebido em 14/02/2014 e aprovado para publicação pelo Conselho Editorial em 10/04/2014.

** Philosophy Unit, Department of General Studies, Ladoke Akintola University of Technology, Ogbomoso, Oyo State, Nigeria. E-mail: omoboy41@gmail.com.
} 


\section{Introduction}

Women worldwide face discrimination in the society. This subordination of women is more pronounced in the developing countries and even more in Nigeria. Studies indicate that at the societal level the discrimination of women is traceable to male authority and decision making in the home, rigid gender roles, definitions of masculinity that are linked to dominance or male honor, economic inequality between men and women, and the use of physical force for conflict resolution (Ezeh and Gage 1998; Morrow (1986).In Africa, cultural subordination of women is blamed on its patriarchal tradition. The family is the main institution of patriarchy (Kate Millet, 1970), which is an important concept in explaining gender inequality. Literarily, the term family means "the rule of the father"; more broadly, it refers to a society ruled and dominated by men over women. This is inherent in most African families. Giving men a higher social status over women has crept into public life, which reflects in state activities. The family plays an important role in maintaining this patriarchal order across generations.

Traditional African societies are replete with norms, customs or values that have affected the life pattern of women in a way that is different from men. These values are usually inculcated into women from childhood. The pattern and the extent of internalization of these values vary from one society to the other. For some societies, the process of internalization is subtle while for others it takes the form of unbridled indoctrination (Ebijuwa 1995).

Before Nigeria's independence in 1960, the British who colonized Nigeria also perpetuated the existing patriarchal tradition by not involving women in the process of governance. They even suppressed the traditional institutions [kingship institution] that protected women against the injustice of the powerful ones in the community. The 1922 Sir Hugh Clifford Constitution disenfranchised women and limited the participation of adult male to the wealthy. This is not to say that there was no existing element of gender inequality in traditional state and stateless societies in Nigeria but that the colonial order made gender discrimination more pronounced. In traditional Yoruba states, for example, women held high political offices like the Iyalode [Women leader in the community], Iyaloja [Market women leader] and even the office of the Oba [King]. But at the establishment of the colonial order, women became estranged to these rights politically, but in the Yoruba Kingdoms they could still perform their traditional roles. Since then, the situation has remained the same, and the Nigeria women has continued to be repressed in politics and in public 
decision-making (Nwankwo, 1996). In Nigeria, women's subordinated position is seen as customary, and their value, which is mirrored in the legal status of women in Nigerian society, has been demoted and women have been reduced to the position of a legal minority under the sponsorship and protection of men for their entire life. (Connors 1988 in Okoronkwo 2001).

\section{Women and elective politics in Nigeria}

Over the years, there has been raging debates over the participation or the desire of women to participate in Nigerian politics. Some argue that: Women are regarded as the weaker sex, and this position is steeped deep in the social value, norms and beliefs of the Nigerian society. As such women's meaningful contributions have been neglected and they have been placed in a subordinate position to men in the nation's political system. This 'sexual division of labour' in the political system is often traced to the onset of colonialism in Nigeria. Politics in Nigeria seems to deliberately frustrate women.

Colonialism, according to Anya (2003), discriminated against women in all spheres of life; be it in property acquisition, commerce, corporate management, access to credit, etc. Feudalism also suppressed women's interests and values. This, in his view, was further assisted by the imported religions which preached total subjugation of women to men, thereby confining their roles to the kitchens and making babies. Even the military regime dealt harshly with women, as they were absent from the public, political scheme of things. It is argued that the male dominated military state reflected the larger patriarchal context and values:

Such norms and values rendered women's struggle to engender politics an uphill and complicated task, as the "opponents" to the gender agenda tended to be in the most dominant institutions of power (Continue Dialogue2001: 56).

In Nigeria, culture seems to have conspired with colonialism and military rule to hold back women from participating in politics. Women are usually called upon in almost every struggle to fight for freedom, change, and democracy. The most unfortunate aspect of the matter is that the fruits of the battle have never been shared equally.

Furthermore, the biggest hurdle against the participation of women in politics in Nigeria is the increasing monetization of political contests. Political contests in Nigeria are also dialectically 
linked to the process of primitive accumulation. The inherent survival and sustenance of the elite is tied to this. Therefore, only those willing to put themselves through a grindstone to oil this process can succeed. Wisdom Dureke, puts it this way:

Our national experience shows that party politics is a huge commercial investment in the country; it is the true poverty eradication project. It gives the contractor politician access to our common wealth for looting. So these contractors want their candidates and their parties to win at all cost get party tickets at all cost too. Here lies the real headache for female aspirants. (CDCPA)

Female candidates are generally considered unusable because of the fact that they will not acquiescent to violence:

The truth of the matter is that many political parties in the country consider female candidacy a risk on the ground that female politicians are not usually keen on doing violence. Political violence, we must acknowledge, has remained one of the best strategies by politicians in the country for electoral victories. Otherwise, how can you explain the increasing incidence of political violence in the country today? Candidates and political parties in different guises recruit thugs and show them off (CDCPA).

Ifeyinwa Ofong argues that the traditional Nigerian attitudes, beliefs, and norms say that a woman should stay at home and care for the children.

She is not expected to participate in politics, which is regarded as a male subject/occupation. This cultural limitation has further constrained the full participation of women in politics. The few women that have dared to seek for elective position in their political parties have been booed and rigged out by their male counterparts (Ofong 2002:4)

Furthermore, Ofong contends that women, unlike their male counterparts, are not likely to receive reinforcement from Nigerian society for participation in politics. He argues that:

The brand of politics being practiced in Nigeria has not helped matters, as a political aspirant would recruit the services of thugs, praise singers and bodyguards (Ofong Ifeyinwa2002)

Adebiyi Bolaji isolates certain socio-stereotypes arising from age-old cultural beliefs that have hindered women's access to politics. According to him: 
Lex Humana, Petrópolis, v. 6, n. 1, p. 1 -8, 2013, ISSN 2175-0947

(C) Universidade Católica de Petrópolis, Petrópolis, Rio de Janeiro, Brasil

Most political activities of consequence occur at night and as such places as hotels and even social clubs. A lot of people, including women would find it irresponsible for a woman to be outside her home at that time of the day or in such "ungodly" places. (Adebiyi Bolaji, 2003)

More so, there seems to be a consensus amongst many that Nigerian politics is based on high political virility - those who succeed are politicians who have all it takes to compete in the turbulent political environment; those who possess the wherewithal to take it by force when force is required; and that is the reason why Adeniyi (2003:353) has identified violence and other forms of electoral conflicts perpetrated and perpetuated by males as the major barriers confronting and inhibiting women's active participation in Nigerian politics. Since men possess superior strength, and competitiveness, self-reliant, and are prepared to tussle in political endeavors, whereas women are considered too passive to engage in politics and governance.

In Nigeria there seems to be no critical understanding of the difference between "a visible agenda for women and an impacting agenda for women." (Nkoyo, 2002:29) While severally, emphasis is laid on women's numerical strength, translating such into the attainment of power has been difficult as women are perceived as "supporters club, team of cheerers and clappers" in contrast to their male counterparts. Women politicians seek offices on the premise of being different; most believe they must do what men are doing to succeed. And the meekness of women is not to their advantage in political tussle.

Furthermore, women's voices have been strident in their quest for power. This is because there are many socio-cultural and educational obstacles that hinder the realization of their objectives; a majority of interested women are relegated to the background because a good percentage of them lack the educational, economic, and political power necessary to actualize their innate potentials. These make the position of most Nigerian women relatively low and remain a disadvantaged group in terms of educational opportunity available in Nigeria. Women have doubted whether changes are necessary and have therefore succumbed to their social roles as mothers and wives. This has grossly affected the participation of women in politics. Coupled with this is the belief that the women's' place is in the kitchen and in the home to take care of children, and not at election rallies or in the speaker's chair (Okoronkwo 2001).

\section{The Way Forward}


Williams (1988), Mabawonku (1988), and Olawoye (1994) have all emphasized the fact that the women are the nutritional bedrock of human society who feed and nurture mankind, and at the same time manages the home. That is the reason why we must interrogate or challenge our culture and set machinery in motion for the eradication of this false image of reality that place women in a permanent position of servitude. This will mean challenging the existing social structures, institutions and practices to (re) position women in the public scene where they can influence decision that affect their lives and those of others. This will allow women, who have long dominated the informal business sectors, to have a sense of belonging and thus command their commitment as stakeholders in the society.

Furthermore, if the practice of democracy in Nigeria is to be reliable women should be included in the political decision-making process and their concerns must be adequately catered to if democracy is to be truly participatory (Okoronkwo 2001). Nigerian democracy should entail equal distribution of private and public responsibilities and a more unbiased presence of men and women in political decision-making bodies. These needs are essential to address gender power imbalances and guarantee good control of government (Mensah, 1998). Therefore, gender equality in male and female participation should be everyone's concern. Women should be given the right to vote and be voted for and not only to vote for. They should also be allowed to occupy higher positions in Nigeria politics by being voted for so as to exhibit their God-given talent for the betterment of the society and the country as a whole. 


\section{References}

ABIOLA, AA (Ms), LANRE A (eds.). Gender Audit - 2003 Election and Issues In Women's

Political Participation In Nigeria: A Publication of Women Advocates Research And Documentation Centre (WARDC), 2003.

BOLAJI, Adebiyi. Women and the 2003 Election: Prospect and Challenge. Assistant Editor of The Punch, 2003.

ADENIYI, E.F. Effects of Political Crises on Women: Towards the Management, 2003.

ADEYEYE, V. A. Women's Involvement in Agriculture and Rural development process. African Notes, Special issue, 3, p. 45-48, 1988.

ANIFOWOSE, R. Women Political Participation in Nigeria: Problems and Prospects in Akinboye SO (ed.). Paradox of Gender Equality in Nigerian Politics. Lagos: Concept Publication Limited, 2004.

ANYA, Okeke. Women and Politics in Nigeria's Fourth Republic in The Constitutional Development (Centre for Constitutionalism and Demilitarisation (CENCOD). Panaf Press, Lagos, 2003.

Democracy In Nigeria: Continuing Dialogue(s) for Nation Building, International Institute for Democracy and Electoral Assistance. IDEA, 2001.

EZEH, A. C. and GAGE, A. J. The Cultural and Economic Context of Domestic Violence in Uganda. Paper presented at the 1998 Annual Meeting of the Population Association of America, Chicago, Illinios, April 1-4, 1998.

HOWARD, R. E. Women and the crisis in Commonwealth Africa International in Nigeria. African Notes, Special issue, 3, p. 17-21, 1985.

KAZI, S. Rural Women, Poverty and Development in Pakistan. Asia-Pacific Journal of Rural Development, 5, 1, p.78-92, 1995.

KENIG, W.M. Women's employment in Africa. Development Bulletin, 37, 27- 29, 1996.

KIRA S. Gender-Related Knowledge and the Descriptive Representation of Women. Political Behaviour, 25, 4, 2003.

KUMAR, S. Dimensions and extent of female labour participation in the low-hill, 1993.

MABAWONKU, A. K. Integrating Women in Fisheries Development: Some Critical Issues of Policy. Paper presented at the National Symposium on promoting Assistance to Rural Women in Fishing Communities, Minna, Nigeria, December 15-17, 1988. 
MENSAH, A. Gender Information, Resolution in Africa. ICT as Tool of Democratization: Africa Women Speak Out, Panos Features, 1998.

MORROW, L. F. Women in Sub- Saharan Africa. In: The Cross-Cultural Study of Women, I.M.

Dudley and M.I. Edwards (eds.). New York: Oxford University Press, 1986.

NKOYO N. Women are looking for new partners for empowerment. Community Magazine CAPP Publication, 5, 1, 2002.

NWANKWO, N. Gender Equality in Nigeria Politics. Lagos: Deutchetz Publishers, 1996.

OFONGIFEYINWA, Women's Participation in Politics in Nigeria (A paper Presented at the $8^{\text {th }}$ International Women's World Congress in Kampala. Uganda, July21-26), 2002.

OKOLIE, A.M. Political Behaviour. Enugu: Academic Publishing Company, 2004.

OKORONKWO, C. Gender Inequalities in Nigeria Politics Unpublished M A. Thesis, 2001.

OLAWOYE, J. E. Women and Forestry in Nigeria. Final report for the Nigeria Forestry, 1994.

Peaceful Resolution of Conflicts in Mike Kwanashie, ed., Politics and Political Power

PHILLIPS A. The Politics of Presence. Oxford: Polity Press, 1995.

ROSALDO MZ, Louise L (Eds). Women, Culture and Society. Stanford University Press, 1974.

The 1999 Constitution of the Federal Republic of Nigeria. UNESCO.Unit for the Promotion of the Status of Women andGender Equality, Passport to Equality, Paris, 1999.

WILLIAMS, S. B. Women's participation in the Fish Industry in Nigeria: A review. Zone agrarian economy of Himachal Pradesh: A case study. Manpower Journal, 29, 2, p.45-59, 1998.

Universidade Católica de Petrópolis

Centro de Teologia e Humanidades

Rua Benjamin Constant, 213 - Centro - Petrópolis

Tel: (24) 2244-4000

lexhumana@ucp.br

http://seer.ucp.br/seer/index.php?journal=LexHumana

OLASUNKANMI, Aborisade. SUBORDINATED BY CULTURE: CONSTRAINTS OF WOMEN IN ELECTIVE POLITICS IN NIGERIA. Lex Humana, v. 6, n. 1, jul. 2014. ISSN 2175-0947. Disponível em: <http://seer.ucp.br/seer/index.php?journal= LexHumana\&page $=$ article\&op=view\&path\%5B\%5D=447>. Acesso em: 01 Jul. 2014. 